\title{
European energy: where now?
}

\section{Chris Sherwell looks at the immediate prospects for European energy policy with Britain in the Council chair}

\begin{abstract}
A SK almost anyone about energy $\mathrm{A}_{\text {policy in the European Community }}$ and the response, when it is not a blank stane, usually reflects deep-seated disillusion. There is no energy policy, some will imply, and there won't be one that is coherent until someone decides how much of what fuels will be needed for what purposes at which points in the future. Others say that only a policy of fully developing all possible sources of energy will fuel Europe's future growth-which, they may add, is what it is all about.

One thing is certain: the future, like nostalgia, is not what it used to be. Hence the gloom. The OECD's recent World Energy Outlook, for example, projecting supply and demand to 1985 , pointedly urged industrialised countries to adopt more vigorous energy policies. The EEC experience certainly doesn't augur well. Francois Xavier-Ortoli, the outgoing president of the European Commission, said as much when he spoke disparagingly of the "feeble" European response to calls for a common energy policy. His successor, Roy Jenkins, stressed only last week the need to develop a coordinated policy. And the outgoing EEC Energy Commissioner, Henri Simonet, has said that EEC governments have accomplished "virtually nothing" on energy.
\end{abstract}

The theme is not always so general. Guido Brunner, the Research Commissioner who has now also taken on the energy portfolio, appealed to Britain a fortnight ago to shift position on the specific issue of the proposed Euratom loans plan; he wants a move on the sensitive issue of a minimum safeguard price for oil (msp) as well. Simonet himself has said that until the Community rids itself of "the ball and chain" of a floor price and gave a go-ahead on Euratom loans it would not be able to develop a policy for boosting alternative energy sources.

\section{Dispelling the log-jam}

Now there are hopes that the log-jam may begin to be dispelled. Mr Brunner's appeal followed a series of meetings held in various European centres by Mr Anthony Wedgwood Benn, the UK Secretary of State for Energy, who now holds the chair of the Council of Ministers because it is Britain's turn under the six-month rotation scheme which the Community operates. Mr Benn's purpose was to learn the objectives of EEC members over the period until July (when Belgium takes over), and to discuss the ways the Council worked.

The date of the first Council meeting under Britain's chairmanship is tentatively set for 4 April. The issues it confronts extend beyond the msp and Euratom loans into the broad nuclear field and into the area of fusion and the Community's JET project as well. On all these matters progress will have been hamstrung for a year to eighteen months by the time the Council meets.

Mr Benn freely acknowledges that the Community has been unsuccessful in energy policy thus far. In an exclusive interview with Nature last week, he described the approach as "too scholastic", with too many people in offices with computer forecasts operating too much from the centre: officials should be made more responsive to politicians, whose shoulders must bear more responsibility.

In Europe, he says, "everything becomes a package deal" and he doesn't want a "haggling relationship". Rather, he wants a realistic one in which the needs of each country, which aren't identical, are taken seriously. The aim is to "harmonise interests", but there is no point in pillorying a country because it can't move. There should be a search for areas of common interest on which people could build a consensus.

Mr Benn says this view is shared by his European colleagues, being more open, more "discussive" and a move away from judging policy by the number of regulations or directives it produces. In energy matters decisions were not always clear and could not always be taken quickly. No policy sticks, he says recalling the Concorde experience, if it isn't also acceptable to public opinion. An energy policy which makes sense will be put together "bit by bit". And it will fall "far short of any 'federal control' of European energy; I think that is absolutely out".

It is on these lines that $\mathrm{Mr}$ Benn wants his Council presidency to be judged. How any success he achieves will manifest itself in the realm of decisions, though, is another matter. $\mathrm{He}$ is reluctant to put priorities on the solution of the many long-standing energy questions facing the Council this year: "We'll have to make progress as and when we can", he states, "and I don't want to set myself a target for a particular decision and then have every meeting which doesn't quite realise it written off as a failure".

\section{Sorry, for copyright reasons some images on this page may not be available online}

\section{Mr Benn: breaking the log-jam?}

\section{Range of problems}

A glance at the topics due to come up during Britain's presidency reveals the problems. They range from the barely answerable, like the rational use of energy, to the arguably unresolvable, like the protection and promotion of investment. It is the latter question which focuses upon the highly controversial issue of the msp, the background to which highlights the sort of difficulty the EEC faces.

Irrelevant symbol or careful calculation, the msp's purpose is to make investment both in the North Sea and on alternative energy sources worthwhile. Britain thinks the msp was agreed by the Community at the end of 1975 when Britain dropped her claim, as EEC's only energy exporter, to speak independently of the Community at the upcoming 'north-south' conference. And most members of the International Energy Agency (IEA), the OECD agency based in Paris, have agreed on the idea. But France-not a member of the IEA because, in her view, it encouraged confrontation with the major oil producers-has firmly resisted an msp, insisting, like $\mathrm{Mr}$ Simonet recently, that only an investment guaranteeing mechanism was agreed.

No one disputes that the msp issue is politically linked to the issue of the Euratom loans, a scheme under which construction of nuclear power stations might go ahead more fluidly by permitting a Community contribution. Germany and France, with their large nuclear programmes, would both benefit by it. Mr Benn himself says he was mandated twelve months ago to agree to a package in Brussels involving both these items. But there was no progress on the msp. EEC countries agreed in principle to the loans scheme, but Britain refused to sanction its implementation without agreement on the msp, even though she had no objection to it and actually stood to benefit by it. The two matters have remained inextricably linked ever since.

There is a parallel linkage in the 
EEC Research Council, now chaired by $\mathrm{Mr}$ Gerald Kaufman from the UK Department of Industry. Its inability to agree on a site for JET, the Community's fusion project, has held up implementation of the four-year joint research programme, most recently because of French insistence that the site be at CERN if not in France itself. The two main contenders are Garching in Germany and Culham in Britain.

The possibility that, with the appointment of $\mathrm{Mr}$ Brunner as both Energy and Research Commissioner, these two sets of linked issues might themselves become linked is not being talked about openly. But $\mathrm{Mr}$ Benn, while pointing out the division of responsibilities between the two Councils, does stress that he is taking a close interest in the subject and affirms that the project is not dead. He could conceivably argue that JET is now to be seen as an energy matter rather than a research project. But for the moment he merely continues to emphasise Britain's view that the Culham site is the most suitable.

\section{JET domino}

In a sense JET is a vital domino in the efforts to stimulate some movement on European energy. Britain for one might find it more difficult to posture over certain aspects of policy if she won JET, although she is highly unlikely to relinquish her self-styled role of remaining Europe's energy equivalent of a 'bread basket' by surrendering sovereignty over North Sea oil and gas.

Yet this idea has been publicly canvassed. It was $\mathrm{Mr}$ Simonet's view at the end of his tenure that Britain should invite other EEC members to join in North Sea exploitation in return for the guaranteed European market she wants even if prices fall: in other words, access to the goods for access to the market. $\mathrm{Mr}$ Benn is fiercely resistant to that suggestion.

$\mathrm{He}$ also resists the notion of dealing with one type of energy investment, in nuclear power for example, without dealing with support for other types. To him there is no trade-off to be made: if Europe is to reduce its dependence on imported energy to some $50 \%$ by 1985 -its intended (if receding) goal-all energy investment must be stimulated.

But even while the haggling goes on over the msp and Euratom loans, the fact remains that Europe will still be the world's largest energy importer in 1985. That, indeed, is why some people say that Europe's nuclear policy, of which the Euratom loans are just one facet, is the most crucial aspect of its energy policy and one which simultaneously offers the best prospect of European cooperation.

The Commission is concerned that the projected nuclear future is now a mere shadow of what it was: the optimistic forecasts of $200 \mathrm{GW}$ of nuclear power by the mid-1980s were reduced to $160 \mathrm{GW}$ some time ago, and according to Simonet the Community would now be lucky to reach $90 \mathrm{GW}$ by then. The problems here, however, stretch beyond mere construction of nuclear power stations.

The EEC countries, all members of Euratom, have so far failed to resolve the now long-standing problem posed by France, which has not signed the Non-Proliferation Treaty, regarding the arrangement for IAEA inspectors to check nuclear installations. France fears IAEA safeguards will be imposed without her consent; her Euratom partners fear she will escape the safeguards they face. One by-product: without agreement on safeguards, a threat to future supplies of enriched uranium from abroad-at a time when at least one of the two European enrichment consortia, Urenco, is facing increasing difficulty.

The issue of reprocessing is still to come on the European front, although reassessment of the matter by the new Carter Administration could have implications for any European intention to reprocess spent fuel on an international basis. $\mathrm{Mr}$ Benn hopes to go to the United States to discuss such matters while Council president, although as a UK minister. But the subject of nuclear fuel supply and the nuclear fuel cycle is only slated to come up in the Council in the second half of 1977.

The work programme for Britain's half of the year includes the subjects of oil refining policy, security of oil stocks, the stockpiling of coal and the use of it in power stations. The Council under Mr Benn may not manage to embrace all these matters as well as make progress on the immediate decisions in the two meetings provisionally planned for April and June.

Past experience of the Council certainly does not offer a happy prognosis. But perhaps the man temporarily at the top can remedy that and confound his critics at the same time. It would indeed be ironic if it was Mr Benn who finally did most to promote European cooperation. That is what is now needed. Matters have reached the stage when the degree to which the old Europeans take Britain seriously over energy policy, and vice versa, is now to be determined.

USA

\section{An unprecedented debate}

Colin Norman reports from Washington on the continuing discussions about genetic manipulation experiments in the United States

AfTER seven months of intense and at times acrimonious debate, the City Council of Cambridge, Massachusetts, last week lifted a moratorium it had placed on some uses of the controversial recombinant DNA genetic engineering technique at Harvard and Massachusetts Institute of Technology. Acting on the advice of a citizens' review board, the council has decided to allow the research to go ahead in Cambridge under strict safety controls and under the watchful eye of a committee of the city's residents.
While the debate in Cambridge has been coming to a resolution, however, it has been picking up momentum in many other parts of the United States. A debate without precedent, it is leading in many cases to an unusual degree of citizens' involvement in the conduct of academic and industrial research, and in the view of many could have a profound influence on future relationships between universities and their surrounding communities.

The following are some of the more important developments which have occurred over the past few weeks.

- New York. Legislation to control recombinant DNA research throughout New York state is expected to be introduced into the state legislature this week. If passed unchanged, it could result in the most stringent controls so far adopted anywhere in the United States.

The legislation is a direct result of a public hearing called last October by the State Attorney General's Office, and the bill was drafted by Deborah Feinberg, an aide in the Attorney General's environmental health bureau. The legislation would essentially require that all academic and industrial research laboratories planning to conduct recombinant DNA experiments must apply for a licence from the state Department of Public Health. The Commissioner of Public Health would be empowered to draft state-wide regulations, based on the NIH guidelines but with additional enforcement provisions. Health monitoring of laboratory personnel would be required, for example, and applicants for licences would have to describe their proposed 